\title{
ANALYSIS OF GHRELIN AND LEPTIN CONCENTRATIONS IN SALIVA IN A SELECTED POPULATION OF CHILDREN AGED 10-13 YEARS IN THE SILESIA PROVINCE (POLAND)
}

\section{ANALIZA STĘŻENIA GRELINY I LEPTYNY W ŚLINIE W WYBRANEJ POPULACJI DZIECI W WIEKU 10-13 LAT W WOJEWÓDZTWIE ŚLĄSKIM (POLSKA)}

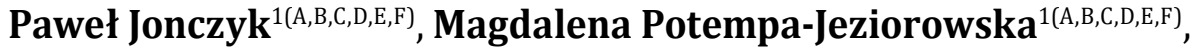 \\ Elżbieta Świętochowska ${ }^{2(A, C, D, E)}$, Marek Kucharzewski ${ }^{1(A, D, E)}$
}

\author{
${ }^{1}$ Department of Descriptive and Topographic Anatomy, Faculty of Medical Sciences in Zabrze, \\ Medical University of Silesia, Katowice, Poland \\ ${ }^{2}$ Department of Medical and Molecular Biology, Faculty of Medical Sciences in Zabrze, Medical University of Silesia, \\ Katowice, Poland
}

Authors' contribution Wkład autorów: A. Study design/planning zaplanowanie badań B. Data collection/entry zebranie danych C. Data analysis/statistics dane - analiza i statystyki D. Data interpretation interpretacja danych E. Preparation of manuscript przygotowanie artykułu F. Literature analysis/search wyszukiwanie i analiza literatury G. Funds collection zebranie funduszy

\section{Summary}

Background. The measurement of salivary ghrelin and leptin concentrations can be a valuable diagnostic tool for assessing children's nutrition.

Material and methods. The study was conducted in a group of children aged 10-13 years in selected elementary schools in the Silesia Province, Poland. Biological material (saliva) was collected from the study children and anthropometric measurements were taken. Collected saliva was subjected to ELISA analysis. Using the obtained anthropometric data, Body Mass Index was calculated, nutritional status of children was determined based on growth charts. Statistical analyses were performed to evaluate the collected data.

Results. A total of 111 children (48 girls and 63 boys) participated in the study. Normal body weight was observed in $55 \%$ of boys and $66 \%$ of girls; overweight was observed in $21 \%$ of girls and $27 \%$ of boys and obesity in $12.5 \%$ of girls and $14.3 \%$ of boys. Ghrelin concentrations in the whole study group correlate significantly with leptin concentrations (Pearson's $r=0.45$; $\mathrm{p}=0.001$ ). Body Mass Index, body weight, waist circumference, as well as hip circumference are statistically associated with ghrelin $(\mathrm{p}=0.001)$ and leptin $(\mathrm{p}=0.001)$ levels.

Conclusions. The factor influencing salivary concentrations of ghrelin and leptin is body weight, whereas gender has no effect on the concentrations of the compounds in question. Body Mass Index values, body weight, height, waist circumference, hip circumference, and waist/hip ratio correlate with salivary concentrations of ghrelin and leptin.

Keywords: ghrelin, leptin, saliva, school children, eating disorders

\section{Streszczenie}

Wprowadzenie. Pomiar stężeń greliny i leptyny w ślinie może stanowić cenne narzędzie diagnostyczne służące ocenie odżywienia dzieci.

Materiał i metody. Badania przeprowadzone zostały w grupie dzieci w wieku 10-13 lat w wybranych szkołach podstawowych w województwie śląskim. Badanym dzieciom pobrano materiał biologiczny (ślinę) oraz dokonano pomiarów antropometrycznych. Pobraną ślinę poddano analizie ELISA. Korzystając z uzyskanych danych antropometrycznych obliczono wskaźnik masy ciała dzieci, ustalono na podstawie siatek centylowych stopień odżywienia dzieci. Dokonano odpowiednich analiz statystycznych.

Wyniki. W badaniu udział wzieło 111 dzieci (48 dziewczynek i 63 chłopców). Prawidłowa masę ciała obserwowano u 55\% chłopców i 66\% dziewczynek, nadwagę stwierdzono u $21 \%$ dziewczynek i $27 \%$ chłopców, a otyłość u 12,5\% dziewczynek i 14,3\% chłopców. Stężenia greliny w całej badanej grupie koreluja znacząco ze stężeniami leptyny (r Pearsona=0,45; $\mathrm{p}=0,001)$. Wskaźnik masy ciała, masa ciała, obwód pasa, jak i obwód bioder są statystycznie związane z poziomem stężenia greliny $(p=0,001)$ i leptyny $(p=0,001)$.

Wnioski. Czynnikiem wpływającym na stężenia greliny i leptyny w ślinie jest masa ciała, natomiast płeć nie ma wpływu na wartości stężeń omawianych związków. Wartość wskaźnika masy ciała, masa ciała, wysokość, obwód pasa, obwód bioder, stosunek talia/biodra korelują ze stężeniami greliny i leptyny w ślinie.
Słowa kluczowe: grelina, leptyna, ślina, dzieci szkolne, zaburzenia stopnia odżwienia
Tables: 10

References: 25

Submitted: 2021 March 16 Accepted: 2021 Apr 22 of children aged 10-13 years in the Silesia Province (Poland). Health Prob Civil. 2021; 15(3): 173-186. https://doi.org/10.5114/hpc.2021.105770

Address for correspondence / Adres korespondencyjny: Paweł Jonczyk, Department of Descriptive and Topographic Anatomy, Faculty of Medical Sciences in Zabrze, Medical University of Silesia, Katowice, Plac Traugutta 2, 41-800 Zabrze, Poland, e-mail: pawel_jonczyk@o2.pl, phone: +48 32 271 7210 ORCID: Paweł Jonczyk https://orcid.org/0000-0001-6968-7371, Magdalena Potempa-Jeziorowska https://orcid.org/0000-0002-7655-0151, Elżbieta Świętochowska https://orcid.org/0000-0001-5787-7880, Marek Kucharzewski https://orcid.org/0000-0001-7950-679X

Copyright: (C) Pope John Paul II State School of Higher Education in Biała Podlaska, Paweł Jonczyk, Magdalena Potempa-Jeziorowska, Elżbieta Świętochowska, Marek Kucharzewski. This is an Open Access journal, all articles are distributed under the terms of the Creative Commons Attribution-NonCommercial-ShareAlike 4.0 International (CC BY-NC-SA 4.0) License (http://creativecommons.org/licenses/by-nc-sa/4.0/), allowing third parties to copy and redistribute the material in any medium or format and to remix, transform, and build upon the material, provided the original work is properly cited and states its license. 


\section{Introduction}

Ghrelin is a 28-amino acid peptide discovered in 1999 that is mainly produced (60-70\% of body production) by X/A neuroendocrine cells in the mucosa of the gastric body and fundus [1]. This hormone is also synthesized in the pituitary gland, intestine, hypothalamus, immune system cells, lungs, kidneys, gonads, placenta, salivary glands, adrenal cortex and pancreas. The key element in the biological activity of this natural hormone is the octenyl group formed by the n-octanoic acid acylation reaction of the hydroxyl group of the third serine. The presence of this functional group allows the hormone to pass through the blood-brain barrier and activate the GHS-R receptor for ghrelin $[1,2]$. This small hormone exhibits multidirectional pleiotropic effects. Among other things, it stimulates the secretion of growth hormone and gastric acid, regulates energy balance, affects the cardiovascular and immune systems, plays a role in bone metabolism, exhibits anti-inflammatory and antiapoptotic effects, affects memory processes and the rhythm of sleep and wakefulness. Ghrelin is secreted mainly in the state of negative energy balance (i.e. during "hunger", hypoglycemia, hypoinsulinemia, stress, during the follicular phase of the monthly cycle or at low body weight), its production is inhibited after food intake, in the state of hyperglycemia and hyperinsulinemia, during "satiety" and in overweight or obese patients [3].

Leptin, on the other hand, is a single-chain polypeptide discovered in 1994 that contains 167 amino acids. It is one of the main adipocytokine protein hormones that inhibit appetite, hence its name from the Greek leptos, meaning slim [4]. It is secreted mainly by adipose tissue and in small amounts by other organs and tissues, e.g., placenta, brain, stomach, mammary glands and skeletal muscles [5,6]. It circulates in the blood in a free form or bound to plasma proteins. Leptin secretion depends on the diurnal rhythm. The highest leptin concentration is observed at night (00:00-2:00 am) and the lowest in the morning (8:00-9:00 am) [7]. The main function of leptin is to inform the so-called "hunger and satiety center" in the hypothalamus about the amount of stored body fat, or energy reservoir. Consequently, leptin affects food intake by decreasing appetite $[3,6]$. The concentration of this hormone varies by gender, with higher blood levels observed in pubescent girls compared to boys of the same age. It has been shown that the amount of leptin released has a positive correlation with Body Mass Index (BMI), while reduction in body fat results in a decrease in blood leptin levels [8]. This hormone also plays an important role in immune processes and enhances wound healing by increasing angiogenesis [6].

Ghrelin and leptin are compounds that play an important role in regulating the body's metabolism. On the one hand, they influence, directly or indirectly, the biochemical processes of carbohydrate, protein, and fat metabolism; on the other hand, they are the main substances regulating both short- and long-term processes of food intake and hunger. Ghrelin and leptin, through their influence on the orexigenic and anorexigenic systems located in the "hunger and satiety centers" in the hypothalamus, enable an appropriate modification of neuroendocrine information (by stimulating or inhibiting the secretion of certain neurotransmitters, including orexins, endocannabinoids, neuropeptide Y (NPY), Agouti-related protein (AgRP), proopiomelanocortin (POMC), and cocaine- and amphetamine-regulated transcript (CART)) in the central nervous system and, consequently, the appropriate regulation of food intake $[3,9,10]$. Therefore, it seems appropriate to call these substances "hunger hormone" for ghrelin and "satiety hormone" for leptin. The close relationship and interconnection between the hormones in the regulation of the body's energy metabolism, body weight and appetite allowed two scientists (Cummings and Foster) to formulate in 2003 the very apt term "ghrelin-leptin tango" [11].

One of the main challenges of modern societies is the fight against the health consequences that they entail. On the one hand, these include the complications of malnutrition in the child population (both qualitative and quantitative shortages), on the other hand, the consequences of hyperalimentation, i.e., the effects of overweight and obesity. Worldwide, approximately $10 \%$ of adolescents aged 5 to 17 years have been found to be overweight or obese, and alarmingly, this percentage has been increasing rapidly in many countries and regions in recent years. Obesity in adolescence is often associated with obesity in adulthood and may also have long-term health consequences, including a higher risk of cardiovascular disease, psychiatric and musculoskeletal disorders, and metabolic diseases $[12,13]$. Equally important seems to be the problem of child malnutrition and hunger in the world, which, as it turns out, is not only characteristic of Third World and developing countries, but also occurs in economically developed countries. Malnutrition is one of the most common causes of growth disorders in children or lower body weight in adults. In addition, micronutrient and macronutrient deficiencies cause, among others, iron deficiency anemia, thyroid end-stage goiter, or abnormal bone formation and reduced peak bone mass [13].

Due to the problem of malnutrition, overweight and obesity in the pediatric population, which is becoming more and more frequent in the contemporary world, and bearing in mind that non-invasive determination of salivary ghrelin and leptin concentrations may be a valuable diagnostic tool in the future for the assessment of the degree of nutrition in children. 


\section{Objectives of the study}

The aim of this study was to determine the ghrelin and leptin concentrations in a selected population of children aged 10-13 years in the Silesia Province, Poland.

The study focused on determining whether overweight or obese girls and boys are statistically different from their normal-weight peers with respect to the variables including salivary ghrelin, leptin, and systolic and diastolic blood pressure values.

The mutual relationships between the above-mentioned variables were evaluated and the correlations of these variables with related factors (directly or indirectly) to body weight, i.e., BMI, height, waist and hip circumference, $\mathrm{W}-\mathrm{H}$ ratio and birth weight, both in the entire study group and in individual subgroups divided according to sex and body weight (normal weight vs. overweight/obesity) were analyzed.

\section{Material and methods}

The study was conducted between 2018 and 2019 in a group of 150 children aged 10-13 years in selected elementary schools in the Silesia Province, after a consent from the principals of the participating schools and written consent from the children's legal guardians had been obtained. The study was conducted within the scope of financing of the scientific-research work under the contract no. KNW-2-029/D/9/N for the realization of scientific-research work by a PhD student of the Medical University of Silesia in Katowice. A consent of the Bioethics Committee of the Medical University of Silesia in Katowice to conduct this scientific study was also obtained (no. KNW/0022/KB1/94/I/18/19).

Saliva samples collected from children who met the following criteria were included in the study:

- child's age 10 to 13 years,

- a correctly completed questionnaire by a parent or legal guardian,

- acquisition of a consent from a parent or legal guardian for the child to participate in the study,

- absence of chronic diseases in the studied child,

- no use of drugs affecting the metabolism of the child's body.

Saliva samples of children with any of the following factors were excluded:

- child's age under 10 years or over 13 years,

- incorrectly or incompletely completed questionnaire by a parent or legal guardian,

- failure to obtain written consent from a parent or legal guardian for the child to participate in the study,

- the presence of chronic diseases in a child (e.g., bronchial asthma, food intolerance, celiac disease, or endocrine disorders such as hypothyroidism or type I diabetes),

- the use of drugs affecting the metabolism of the child (e.g. corticosteroids, L-thyroxine or insulin).

During the meeting, an anonymous questionnaire was distributed to parents containing questions about their child's health history (chronic illnesses, medications taken consistently, infancy). Basic anthropometric measurements of the children (body weight, height, hip and waist circumference), blood pressure measurements were performed, and saliva was collected into Sarstedt's Salivettes for further testing. Biological material was collected from the children after they had abstained from food and drink for 30 minutes. The cotton swab was then advised to be chewed for about 30-45 seconds and secured in a Salivette. The obtained biological material was transported in a refrigerator to the laboratory of the Department of Medical and Molecular Biology, Faculty of Medical Sciences in Zabrze, the Medical University of Silesia in Katowice. Salivary ghrelin concentrations were determined by enzyme-linked immunosorbent assay (ELISA) using Cloud-Clone Corp. (USA) cat. no. CEA99 1Hu, according to the manufacturer's instructions. Absorbance readings were performed using a Universal Microplate Spectrophotometer- $\mu$ QUANT reader from BIO-TEK INC (Bio-Tek World Headquarters, California, USA) at 450 $\mathrm{nm}$ and a reference wavelength of $630 \mathrm{~nm}$. The processing of the results was done using the computer program KCJunior (Bio-Tek, USA). The sensitivity of the kit was $49.5 \mathrm{pg} / \mathrm{ml}$. In turn, leptin concentrations were determined by ELISA, using an assay from Bio-Vendor LLC (BioVendor - Laboratorní medicína, Czech Republic) - Human Leptin ELISA, Clinical Range, cat. no. RD 191001100, according to the manufacturer's instructions. Absorbance readings were performed using the Universal Microplate Spectrophotometer- $\mu$ QUANT reader from BIO-TEK INC (Bio-Tek World Headquarters, California, USA) at $450 \mathrm{~nm}$, and the processing of results was performed using the KCJunior computer program (Bio-Tek, USA). The sensitivity of the kit was $0.2 \mathrm{ng} / \mathrm{ml}$.

On the basis of anthropometric measurements and calculated BMI indices, the degree of nutrition of the examined children was determined according to European standards. It was assumed that underweight refers to a child whose BMI is below the 5th percentile in the growth chart for the population relative to age and sex, overweight was defined as a BMI between the 85th and 95th percentile, and obesity was defined as above the 95th percentile. 
The data obtained from the study were statistically analyzed using IBM SPSS Statistics version 25 statistical package. Comparative analyses were performed using the Kruskal-Wallis and Mann Whitney U nonparametric tests. In contrast, correlation analyses were performed using both Pearson's parametric $r$ coefficient and Spearman's non-parametric rho coefficient. A p-value of 0.05 was established as the level of significance, while p-value results between 0.05 and $0.1(0.05<\mathrm{p}<0.1)$ were considered to indicate the significance of the test as within the statistical trend.

\section{Results}

\section{Analysis of children's nutritional status}

A total of 111 children between the ages of 10 and 13 participated in the study. The remaining 39 subjects were ineligible for the study due to failure to meet the inclusion criterion or inability to determine salivary concentrations of the test compounds. The mean age in the entire study group was over 11 years (M=11.41, $\mathrm{SD}=1.05)$. The number of girls $(\mathrm{n}=48)$ was lower than the number of boys $(n=63)$. The girls (in every age group analyzed) had predominantly a normal body weight. Both overweight and obesity were most common among 11-year-old girls. There was not a single case of underweight among the studied group of girls. Obesity affected $12.5 \%$ of all girls and additional $21 \%$ of girls were overweight. Normal body weight in relation to height and sex was reported in more than $66 \%$ of the girls studied. A detailed breakdown of female children considering their age and weight is provided in Table 1 . Similar characteristics to those for girls were reported for boys. Most of the male children were characterized by normal body weight (55.56\%). Obesity affected $14.3 \%$ of all boys and almost $27 \%$ of them were overweight. The highest number of overweight/obese boys was observed among 11-year-olds. In addition, two subjects were classified as underweight (approximately 3\%). The breakdown of boys by age and weight is presented in Table 2 .

Table 1. Percentage distribution of the studied girls by age and body weight

\begin{tabular}{|c|c|c|c|c|c|c|c|c|}
\hline \multirow{2}{*}{ Age } & \multicolumn{2}{|c|}{ underweight } & \multicolumn{2}{c|}{ normal weight } & \multicolumn{2}{c|}{ overweight } & \multicolumn{2}{c|}{ obesity } \\
\cline { 2 - 10 } & $\boldsymbol{n}$ & $\mathbf{\%}$ & $\boldsymbol{n}$ & $\mathbf{\%}$ & $\boldsymbol{n}$ & $\boldsymbol{\%}$ & $\boldsymbol{n}$ & \% \\
\hline 10 years old & 0 & 0.0 & 7 & 70.0 & 2 & 20.0 & 1 & 10.0 \\
\hline 11 years old & 0 & 0.0 & 6 & 42.9 & 5 & 35.7 & 3 & 21.4 \\
\hline 12 years old & 0 & 0.0 & 13 & 81.3 & 3 & 18.8 & 0 & 0.0 \\
\hline 13 years old & 0 & 0.0 & 6 & 75.0 & 0 & 0.0 & 2 & 25.0 \\
\hline
\end{tabular}

Table 2. Percentage distribution of the studied boys by age and body weight

\begin{tabular}{|c|c|c|c|c|c|c|c|c|}
\hline \multirow{2}{*}{ Age } & \multicolumn{2}{|c|}{ underweight } & \multicolumn{2}{c|}{ normal weight } & \multicolumn{2}{c|}{ overweight } & \multicolumn{2}{c|}{ obesity } \\
\cline { 2 - 10 } & $\boldsymbol{n}$ & $\mathbf{\%}$ & $\boldsymbol{n}$ & $\mathbf{\%}$ & $\boldsymbol{n}$ & $\mathbf{\%}$ & $\boldsymbol{n}$ & \% \\
\hline 10 years old & 1 & 5.9 & 10 & 58.8 & 5 & 29.4 & 1 & 5.9 \\
\hline 11 years old & 1 & 5.6 & 7 & 38.9 & 7 & 38.9 & 3 & 16.7 \\
\hline 12 years old & 0 & 0.0 & 11 & 68.8 & 3 & 18.8 & 2 & 12.5 \\
\hline 13 years old & 0 & 0.0 & 7 & 58.3 & 2 & 16.7 & 3 & 25.0 \\
\hline
\end{tabular}

Before proceeding, basic descriptive statistics were calculated along with Kolmogorov-Smirnov (for groups $n \geq 100$ ) and Shapiro-Wilk (for groups $n<100$ ) normality tests of the distribution. These analyses were conducted for all quantitative variables that were included in the paper. Due to the nature of further analyses (investigation of intergroup differences), calculations were performed in the entire study group and by subgroups separated by sex and weight (normal weight vs. overweight/obesity). Because of the small proportion of underweight children $(n=2)$, this group of subjects was not included in the comparative analyses. It was found that the distribution of some variables deviated significantly from the normal distribution. Because of this and given the unequal size of the subgroups compared, non-parametric tests were used in the comparative analyses. In contrast, both nonparametric and parametric tests were used in the correlation analyses (depending on whether the criteria for a particular test were met). The results are presented in Table 3. 
Table 3. Basic descriptive statistics with the normality of distribution test for quantitative variables included in the design in the entire study group and in individual subgroups based on the body weight (normal vs. overweight/obesity)

\begin{tabular}{|c|c|c|c|c|c|c|c|c|c|}
\hline & $M$ & $M e$ & $S D$ & Sk. & Kurt. & Min. & Max. & $\begin{array}{l}K-S / \\
S-W\end{array}$ & $p$ \\
\hline \multicolumn{10}{|c|}{ All Study Group (n=111) } \\
\hline BMI & 20.14 & 19.56 & 3.57 & 0.46 & -0.40 & 13.14 & 29.53 & 0.09 & 0.041 \\
\hline Weight [kg] & 45.07 & 44.00 & 10.87 & 0.58 & 0.54 & 24.30 & 83.00 & 0.07 & 0.198 \\
\hline Height [m] & 1.51 & 1.51 & 0.10 & 0.13 & -0.37 & 1.29 & 1.75 & 0.07 & 0.200 \\
\hline Waist circumference [cm] & 72.46 & 71.00 & 10.35 & 0.70 & 0.05 & 55.00 & 101.00 & 0.08 & 0.058 \\
\hline Hip circumference [cm] & 80.90 & 80.00 & 9.98 & 0.29 & 0.28 & 55.00 & 108.00 & 0.07 & 0.200 \\
\hline W-H Ratio & 0.90 & 0.90 & 0.06 & 0.43 & 0.32 & 0.76 & 1.05 & 0.08 & 0.063 \\
\hline Ghrelin concentration $[\mathrm{pg} / \mathrm{ml}]$ & 168.86 & 169.33 & 33.08 & 0.93 & 0.64 & 110.93 & 264.51 & 0.12 & 0.001 \\
\hline Leptin concentration [ng/ml] & 6.03 & 5.79 & 1.84 & 0.42 & -0.24 & 2.35 & 10.89 & 0.06 & 0.200 \\
\hline Systolic pressure [mmHg] & 112.66 & 110.00 & 10.53 & 0.09 & -0.39 & 90.00 & 140.00 & 0.20 & 0.001 \\
\hline Diastolic pressure [mmHg] & 76.31 & 80.00 & 10.70 & 0.03 & -0.27 & 50.00 & 100.00 & 0.18 & 0.001 \\
\hline Birth weight [g] & 3415.68 & 3450.00 & 417.99 & -0.05 & -0.26 & 2500.00 & 4600.00 & 0.07 & 0.200 \\
\hline \multicolumn{10}{|c|}{ Girls with normal weight $(n=32)$} \\
\hline BMI & 17.92 & 17.74 & 1.62 & 0.50 & -0.49 & 15.41 & 21.36 & 0.95 & 0.182 \\
\hline Weight [kg] & 41.49 & 42.70 & 7.64 & 0.08 & 0.13 & 27.50 & 61.00 & 0.97 & 0.599 \\
\hline Height [m] & 1.52 & 1.52 & 0.10 & -0.51 & -0.22 & 1.29 & 1.69 & 0.96 & 0.243 \\
\hline Waist circumference $[\mathrm{cm}]$ & 67.05 & 67.50 & 5.41 & -0.24 & -0.79 & 56.00 & 76.00 & 0.97 & 0.466 \\
\hline Hip circumference $[\mathrm{cm}]$ & 76.72 & 77.00 & 6.78 & -0.45 & 0.05 & 59.00 & 88.00 & 0.98 & 0.665 \\
\hline W-H Ratio & 0.88 & 0.88 & 0.04 & -0.26 & -0.10 & 0.76 & 0.95 & 0.96 & 0.300 \\
\hline Ghrelin concentration $[\mathrm{pg} / \mathrm{ml}]$ & 155.78 & 145.82 & 27.07 & 1.25 & 2.69 & 115.78 & 247.41 & 0.90 & 0.007 \\
\hline Leptin concentration $[\mathrm{ng} / \mathrm{ml}]$ & 5.12 & 4.88 & 1.29 & 0.18 & 0.10 & 2.35 & 8.35 & 0.99 & 0.964 \\
\hline Systolic pressure [mmHg] & 112.19 & 110.00 & 10.70 & 0.04 & -0.04 & 90.00 & 130.00 & 0.88 & 0.002 \\
\hline Diastolic pressure [mmHg] & 77.34 & 80.00 & 11.22 & -0.47 & 0.05 & 50.00 & 100.00 & 0.92 & 0.023 \\
\hline Birth weight [g] & 3324.69 & 3360.00 & 399.70 & -0.09 & -0.57 & 2500.00 & 4000.00 & 0.97 & 0.543 \\
\hline \multicolumn{10}{|c|}{ Overweight/obese girls $(n=16)$} \\
\hline BMI & 23.52 & 22.48 & 2.43 & 1.17 & 1.00 & 20.49 & 29.53 & 0.88 & 0.040 \\
\hline Weight [kg] & 49.27 & 47.40 & 11.99 & 0.33 & -0.57 & 32.00 & 73.50 & 0.96 & 0.688 \\
\hline Height [m] & 1.49 & 1.49 & 0.10 & 0.95 & 0.22 & 1.38 & 1.73 & 0.89 & 0.061 \\
\hline Waist circumference $[\mathrm{cm}]$ & 78.88 & 80.00 & 11.67 & -0.18 & -0.22 & 58.00 & 98.00 & 0.95 & 0.489 \\
\hline Hip circumference $[\mathrm{cm}]$ & 86.94 & 88.00 & 13.26 & -0.74 & 1.03 & 55.00 & 108.00 & 0.95 & 0.431 \\
\hline W-H Ratio & 0.91 & 0.91 & 0.05 & 1.07 & 1.75 & 0.85 & 1.05 & 0.91 & 0.120 \\
\hline Ghrelin concentration $[\mathrm{pg} / \mathrm{ml}]$ & 181.46 & 176.47 & 27.87 & 1.54 & 2.70 & 145.69 & 253.22 & 0.82 & 0.005 \\
\hline Leptin concentration $[\mathrm{ng} / \mathrm{ml}]$ & 7.24 & 7.20 & 1.31 & -0.05 & -0.76 & 5.21 & 9.53 & 0.96 & 0.679 \\
\hline Systolic pressure [mmHg] & 115.63 & 120.00 & 10.94 & 0.34 & 0.34 & 100.00 & 140.00 & 0.90 & 0.073 \\
\hline Diastolic pressure [mmHg] & 75.31 & 75.00 & 10.56 & 0.63 & 0.66 & 60.00 & 100.00 & 0.91 & 0.124 \\
\hline Birth weight [g] & 3293.13 & 3400.00 & 339.41 & -0.30 & -1.08 & 2700.00 & 3820.00 & 0.95 & 0.464 \\
\hline \multicolumn{10}{|c|}{ Boys with normal weight $(n=35)$} \\
\hline BMI & 18.11 & 18.37 & 1.92 & -0.27 & -0.82 & 14.38 & 21.33 & 0.96 & 0.230 \\
\hline Weight [kg] & 43.21 & 42.00 & 8.74 & 0.25 & -0.32 & 27.50 & 64.00 & 0.98 & 0.667 \\
\hline Height [m] & 1.53 & 1.52 & 0.11 & 0.17 & -0.49 & 1.32 & 1.75 & 0.98 & 0.645 \\
\hline Waist circumference $[\mathrm{cm}]$ & 70.06 & 70.00 & 6.73 & 0.24 & -0.54 & 60.00 & 87.00 & 0.95 & 0.121 \\
\hline Hip circumference $[\mathrm{cm}]$ & 78.50 & 80.00 & 6.52 & -0.48 & 0.50 & 60.00 & 91.00 & 0.97 & 0.449 \\
\hline W-H Ratio & 0.91 & 0.89 & 0.06 & 0.49 & 0.07 & 0.78 & 1.03 & 0.95 & 0.118 \\
\hline Ghrelin concentration $[\mathrm{pg} / \mathrm{ml}]$ & 159.72 & 159.61 & 24.97 & 0.97 & 0.65 & 129.62 & 225.43 & 0.90 & 0.004 \\
\hline
\end{tabular}




\begin{tabular}{|c|c|c|c|c|c|c|c|c|c|c|}
\hline Leptin concentration [ng/m] ] & 5.23 & 5.17 & 1.32 & -0.07 & -0.68 & 2.65 & 7.91 & 0.98 & 0.837 \\
\hline Systolic pressure [mmHg] & 111.43 & 110.00 & 9.67 & 0.14 & -0.32 & 90.00 & 130.00 & 0.92 & 0.014 \\
\hline Diastolic pressure [mmHg] & 76.14 & 80.00 & 9.56 & 0.38 & -0.13 & 60.00 & 100.00 & 0.91 & 0.005 \\
\hline Birth weight [g] & 3486.29 & 3590.00 & 467.18 & -0.04 & -0.10 & 2500.00 & 4600.00 & 0.97 & 0.577 \\
\hline \multicolumn{7}{|c|}{ 0verweight/obese boys $(\boldsymbol{n}=\mathbf{2 6})$} \\
\hline BMI & 24.05 & 24.16 & 2.28 & 0.20 & -1.43 & 20.82 & 28.06 & 0.91 & 0.030 \\
\hline Weight [kg] & 50.78 & 49.90 & 12.80 & 0.23 & 0.36 & 29.00 & 83.00 & 0.97 & 0.706 \\
\hline Height [m] & 1.51 & 1.51 & 0.09 & 0.19 & 0.15 & 1.34 & 1.72 & 0.99 & 0.968 \\
\hline Waist circumference [cm] & 79.67 & 81.00 & 11.99 & -0.12 & -0.95 & 59.00 & 101.00 & 0.96 & 0.426 \\
\hline Hip circumference [cm] & 86.65 & 86.00 & 10.63 & -0.20 & -0.61 & 67.00 & 108.00 & 0.96 & 0.405 \\
\hline W-H Ratio & 0.93 & 0.93 & 0.06 & 0.02 & 0.69 & 0.81 & 1.05 & 0.95 & 0.215 \\
\hline Ghrelin concentration [pg/ml] & 192.34 & 186.49 & 38.34 & 0.22 & -0.42 & 110.93 & 264.51 & 0.95 & 0.191 \\
\hline Leptin concentration [ng/ml] & 7.68 & 7.47 & 1.80 & -0.04 & -0.87 & 4.38 & 10.89 & 0.97 & 0.631 \\
\hline Systolic pressure [mmHg] & 113.65 & 115.00 & 11.45 & -0.23 & -0.92 & 90.00 & 130.00 & 0.91 & 0.029 \\
\hline Diastolic pressure [mmHg] & 76.35 & 72.50 & 12.29 & -0.06 & -0.57 & 50.00 & 100.00 & 0.93 & 0.065 \\
\hline Birth weight [g] & 3504.62 & 3570.00 & 405.60 & -0.43 & 0.01 & 2500.00 & 4200.00 & 0.97 & 0.639 \\
\hline
\end{tabular}

\section{Hormone levels in relation to sex and body weight}

The first analysis sought to determine whether children differed in levels of selected hormones depending on sex and/or body weight (normal weight vs. overweight/obesity). According to the results presented in Table 4 , the study groups were significantly different in terms of ghrelin and leptin levels. The mean salivary ghrelin concentration in the group of girls with normal body weight was $155.78 \mathrm{pg} / \mathrm{ml}$, while in the overweight or obese girls group it was $181.46 \mathrm{pg} / \mathrm{ml}$. In the group of boys with normal body weight the mean ghrelin concentration values were equal to $159.72 \mathrm{pg} / \mathrm{ml}$ and in the overweight or obese boys' group it was $192.34 \mathrm{pg} / \mathrm{ml}$. In contrast, the mean salivary leptin concentration in the population of girls with normal weight was $5.12 \mathrm{ng} / \mathrm{ml}$, while in the overweight or obese group it was $7.24 \mathrm{ng} / \mathrm{ml}$. In the population of boys with normal weight the mean values of salivary leptin concentration were $5.23 \mathrm{ng} / \mathrm{ml}$ and in the group of overweight or obese boys the value was $7.68 \mathrm{ng} / \mathrm{ml}$.

Table 4. Mean scores, standard deviations and significance of differences in concentration levels of selected compounds depending on the sex and body weight (normal weight vs. overweight/obesity)

\begin{tabular}{|c|c|c|c|c|c|c|c|c|c|c|c|}
\hline & \multicolumn{2}{|c|}{$\begin{array}{l}\text { Girls with } \\
\text { normal body } \\
\text { weight } \\
(n=32)\end{array}$} & \multicolumn{2}{|c|}{$\begin{array}{c}\text { Overweight/ } \\
\text { obese girls } \\
(n=16)\end{array}$} & \multicolumn{2}{|c|}{$\begin{array}{l}\text { Boys with } \\
\text { normal body } \\
\text { weight } \\
(n=35)\end{array}$} & \multicolumn{2}{|c|}{$\begin{array}{c}\text { Overweight/ } \\
\text { obese boys } \\
(n=26)\end{array}$} & \multirow[t]{2}{*}{$\mathbf{H}$} & \multirow[t]{2}{*}{$\mathbf{p}$} & \multirow[t]{2}{*}{$\mathbf{E}^{2}$} \\
\hline & M & SD & M & SD & M & SD & M & SD & & & \\
\hline $\begin{array}{c}\text { Ghrelin } \\
\text { concentration } \\
{[\mathrm{pg} / \mathrm{ml}]}\end{array}$ & 155.78 & 27.07 & 181.46 & 27.87 & 159.72 & 24.97 & 192.34 & 38.34 & 24.04 & 0.001 & 0.22 \\
\hline $\begin{array}{c}\text { Leptin } \\
\text { concentration } \\
{[\mathrm{ng} / \mathrm{ml}]}\end{array}$ & 5.12 & 1.29 & 7.24 & 1.31 & 5.23 & 1.32 & 7.68 & 1.80 & 41.91 & 0.001 & 0.39 \\
\hline
\end{tabular}

In order to determine whether there were significant differences between the groups in the aforementioned variables, calculations were performed using the Mann Whitney U test. The results showed that children with normal body weight were statistically significantly different from overweight/obese children in terms of ghrelin and leptin levels (Table 5). Overweight/obese participants had significantly higher levels of the studied hormones compared to individuals with normal weight. The significance of the effect of these differences was moderate to high. No gender differences were observed in the variables studied. Thus, it can be concluded that body weight (normal weight vs. overweight/obesity) is a factor that differentiates the levels of the studied hormones, while gender does not modify the results in terms of these variables. 
Table 5. Significance of intergroup differences in selected compounds

\begin{tabular}{|c|c|c|c|c|}
\hline & & $\mathbf{U}$ & p & $\mathbf{r}$ \\
\hline \multirow{6}{*}{ 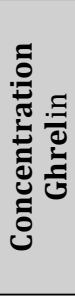 } & Girls with normal body weight vs. overweight/obese girls & 118.00 & 0.003 & -0.54 \\
\hline & Girls with normal body weight vs. boys with normal body weight & 509.50 & 0.526 & -0.09 \\
\hline & Girls with normal body weight vs. overweight/obese boys & 174.50 & 0.001 & -0.58 \\
\hline & Boys with normal body weight vs. overweight/obese girls & 199.50 & 0.001 & -0.56 \\
\hline & Boys with normal body weight vs. overweight/obese girls & 135.00 & 0.003 & -0.52 \\
\hline & Overweight/obese girls vs. overweight/obese girls & 172.00 & 0.351 & -0.17 \\
\hline \multirow{6}{*}{ 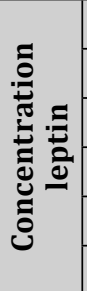 } & Girls with normal body weight vs. overweight/obese girls & 60.50 & 0.001 & -0.76 \\
\hline & Girls with normal body weight vs. boys with normal body weight & 522.50 & 0.638 & -0.07 \\
\hline & Girls with normal body weight vs. overweight/obese boys & 105.00 & 0.001 & -0.75 \\
\hline & Boys with normal body weight vs. overweight/obese girls & 128.00 & 0.001 & -0.72 \\
\hline & Boys with normal body weight vs. overweight/obese girls & 77.00 & 0.001 & -0.73 \\
\hline & Overweight/obese girls vs. overweight/obese girls & 170.00 & 0.325 & -0.18 \\
\hline
\end{tabular}

Correlations between salivary ghrelin and leptin concentrations in selected subgroups of children

The subsequent analysis examined whether there were significant associations between the hormones studied. Calculations were performed on the entire study group and then on individual subgroups. Pearson's $r$ correlation coefficient was used to determine the correlations. The data presented in Table 6 show that there were statistically significant relationships between selected hormones among the children studied. As it turned out, the level of ghrelin concentration in the whole study group correlated significantly with the level of leptin concentration (positive correlation, Pearson's $r=0.45 ; \mathrm{p}=0.001$ ). Analogous analyses were performed in groups determined according to sex and body weight (normal weight vs. overweight/obesity). Underweight children were excluded from the analyses. The calculated Pearson's $r$ and significance coefficients for the different subgroups studied were as follows:

- girls with normal body weight ( $n=32): r=0.26 ; p=0.154$;

- overweight/obese girls $(n=16): r=0.10 ; p=0.719$;

- boys with normal body weight $(n=35): r=0.14 ; p=0.418$;

- overweight/obese boys $(n=26): r=0.26 ; p=0.200$.

Table 6. Correlations between selected variables in the entire study group $(n=111)$

\begin{tabular}{|c|c|c|c|}
\hline & & Ghrelin concentration & Leptin concentration \\
\hline \multirow{2}{*}{ Ghrelin concentration } & Pearson's r & - & 0.45 \\
\hline & significance & - & 0.001 \\
\hline \multirow{2}{*}{ Leptin concentration } & Pearson's r & 0.45 & - \\
\hline & significance & 0.001 & - \\
\hline
\end{tabular}

Correlations of ghrelin and leptin levels with weight-related variables

Subsequent analyses focused on the correlations between salivary ghrelin and leptin concentrations and weight-related variables. The first analysis of the above relationships was performed on the entire study group. The results showed that the variables related to body weight, namely BMI, height, waist circumference, hip circumference and waist/hip ratio $(\mathrm{W}-\mathrm{H})$, correlate significantly with the levels of the hormones studied. However, there was no correlation between birth weight and the concentration of the hormones in question. According to the data in Table 7, BMI is statistically significantly associated with ghrelin $(\mathrm{p}=0.001)$ and leptin $(p=0.001)$ levels. The direction of these relationships is positive, meaning that as BMI increases, the concentration of the aforementioned hormones increases. Body weight correlates significantly with ghrelin $(p=0.001)$, leptin $(p=0.001)$ levels. Height correlates significantly with ghrelin concentration $(p=0.036)$. Both waist circumference and hip circumference are associated with concentrations of ghrelin (positive correlation, $p=0.001$ ) and leptin (positive correlation, $\mathrm{p}=0.001$ ). The $\mathrm{W}-\mathrm{H}$ ratio correlated significantly with ghrelin and leptin concentrations, the direction of these relationships being positive $(\mathrm{p}=0.004 ; \mathrm{p}=0.007$, respectively). As it turned out, birth weight is not associated with the levels of the studied compounds $(p=0.172 ; p=0.874$, respectively). 
Table 7. Correlations of ghrelin and leptin levels with weight-related variables in different study subgroups

\begin{tabular}{|c|c|c|c|c|c|c|c|c|c|c|c|}
\hline & & \multicolumn{2}{|c|}{$\begin{array}{c}\text { Study group } \\
(n=111)\end{array}$} & \multicolumn{2}{|c|}{$\begin{array}{l}\text { Girls with normal } \\
\text { body weight }(n=32)\end{array}$} & \multicolumn{2}{|c|}{$\begin{array}{c}\text { Overweight/obese } \\
\text { girls }(\mathrm{n}=16)\end{array}$} & \multicolumn{2}{|c|}{$\begin{array}{c}\text { Boys with normal } \\
\text { body weight }(n=35)\end{array}$} & \multicolumn{2}{|c|}{$\begin{array}{c}\text { Overweight/obese } \\
\text { boys }(n=26)\end{array}$} \\
\hline & & 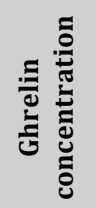 & : & : & 总 & 壱 & 节 & 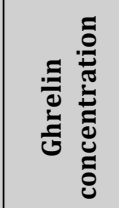 & 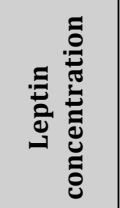 & 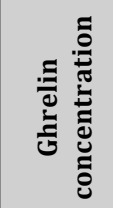 & 䒿 \\
\hline \multirow{2}{*}{ BMI } & Pearson's $r$ & 0.65 & 0.74 & 0.66 & 0.46 & 0.32 & 0.01 & 0.53 & 0.55 & 0.54 & 0.67 \\
\hline & significance & 0.001 & 0.001 & 0.001 & 0.008 & 0.232 & 0.966 & 0.001 & $<0,001$ & 0.004 & $<0,001$ \\
\hline \multirow{2}{*}{ Weight } & Pearson's r & 0.49 & 0.38 & 0.60 & 0.39 & 0.32 & -0.18 & 0.39 & 0.53 & 0.27 & -0.02 \\
\hline & significance & 0.001 & 0.001 & 0.001 & 0.026 & 0.225 & 0.506 & 0.019 & $<0,001$ & 0.176 & 0.924 \\
\hline \multirow{2}{*}{ Height } & Pearson's r & 0.20 & 0.07 & 0.37 & 0.22 & 0.19 & -0.04 & 0.15 & 0.36 & 0.32 & -0.10 \\
\hline & significance & 0.036 & 0.461 & 0.040 & 0.235 & 0.491 & 0.896 & 0.396 & 0.034 & 0.116 & 0.639 \\
\hline \multirow{2}{*}{\begin{tabular}{|c|} 
Waist \\
circumference
\end{tabular}} & Pearson's r & 0.46 & 0.34 & 0.42 & 0.16 & 0.03 & -0.27 & 0.27 & 0.27 & 0.33 & -0.14 \\
\hline & significance & 0.001 & 0.001 & 0.018 & 0.377 & 0.911 & 0.305 & 0.123 & 0.111 & 0.096 & 0.484 \\
\hline \multirow{2}{*}{$\begin{array}{c}\text { Hip } \\
\text { circumference }\end{array}$} & Pearson's r & 0.42 & 0.31 & 0.51 & 0.19 & -0.01 & -0.11 & 0.30 & 0.26 & 0.23 & -0.17 \\
\hline & significance & 0.001 & 0.001 & 0.003 & 0.298 & 0.962 & 0.676 & 0.077 & 0.138 & 0.264 & 0.402 \\
\hline \multirow{2}{*}{$\begin{array}{c}\text { Ratio } \\
\text { W-H }\end{array}$} & Pearson's r & 0.27 & 0.25 & -0.23 & -0.09 & 0.08 & -0.38 & 0.18 & 0.34 & 0.36 & 0.10 \\
\hline & significance & 0.004 & 0.007 & 0.204 & 0.629 & 0.755 & 0.146 & 0.305 & 0.047 & 0.067 & 0.634 \\
\hline \multirow{2}{*}{ Birth weight } & Pearson's r & 0.13 & 0.02 & 0.29 & 0.09 & 0.28 & 0.31 & 0.11 & -0.13 & -0.07 & -0.08 \\
\hline & significance & 0.172 & 0.874 & 0.101 & 0.643 & 0.288 & 0.237 & 0.534 & 0.455 & 0.751 & 0.681 \\
\hline
\end{tabular}

Systolic and diastolic blood pressure values according to sex and body weight

The next analysis evaluated if there were differences between the study subgroups of children in systolic and diastolic blood pressure according to sex and weight (normal weight vs. overweight/obesity). Because of the unequal groups, the calculations relied on the nonparametric Kruskal-Wallis test. According to the data presented in Table 8, factors such as gender and body weight (normal vs. overweight/obesity) did not differentiate blood pressure values ( $\mathrm{p}=0.583$ - for systolic blood pressure values, $\mathrm{p}=0.811$ - for diastolic blood pressure values). The results obtained are also presented in graphical form (Figure 1).

Table 8. Mean scores, standard deviations, and significance of differences in systolic and diastolic blood pressure by sex and weight (normal weight vs. overweight/obesity)

\begin{tabular}{|c|c|c|c|c|c|c|c|c|c|c|c|}
\hline & \multicolumn{2}{|c|}{$\begin{array}{c}\text { Girls with } \\
\text { normal body } \\
\text { weight } \\
(n=32)\end{array}$} & \multicolumn{2}{|c|}{$\begin{array}{l}\text { Overweight/ } \\
\text { obese girls } \\
\text { (n=16) }\end{array}$} & \multicolumn{2}{|c|}{$\begin{array}{c}\text { Boys with } \\
\text { normal body } \\
\text { weight } \\
(n=35) \\
\end{array}$} & \multicolumn{2}{|c|}{$\begin{array}{l}\text { Overweight/ } \\
\text { obese boys } \\
\text { (n=26) }\end{array}$} & \multirow[t]{2}{*}{$\boldsymbol{H}$} & \multirow[t]{2}{*}{$p$} & \multirow[t]{2}{*}{$\mathbf{E}^{2}$} \\
\hline & $M$ & $S D$ & $M$ & $S D$ & $M$ & $S D$ & $M$ & $S D$ & & & \\
\hline $\begin{array}{c}\text { Systolic blood } \\
\text { pressure }\end{array}$ & 112.19 & 10.70 & 115.63 & 10.94 & 111.43 & 9.67 & 113.65 & 11.45 & 1.95 & 0.583 & 0.02 \\
\hline $\begin{array}{c}\text { Diastolic blood } \\
\text { pressure }\end{array}$ & 77.34 & 11.22 & 75.31 & 10.56 & 76.14 & 9.56 & 76.35 & 12.29 & 0.96 & 0.811 & 0.01 \\
\hline
\end{tabular}




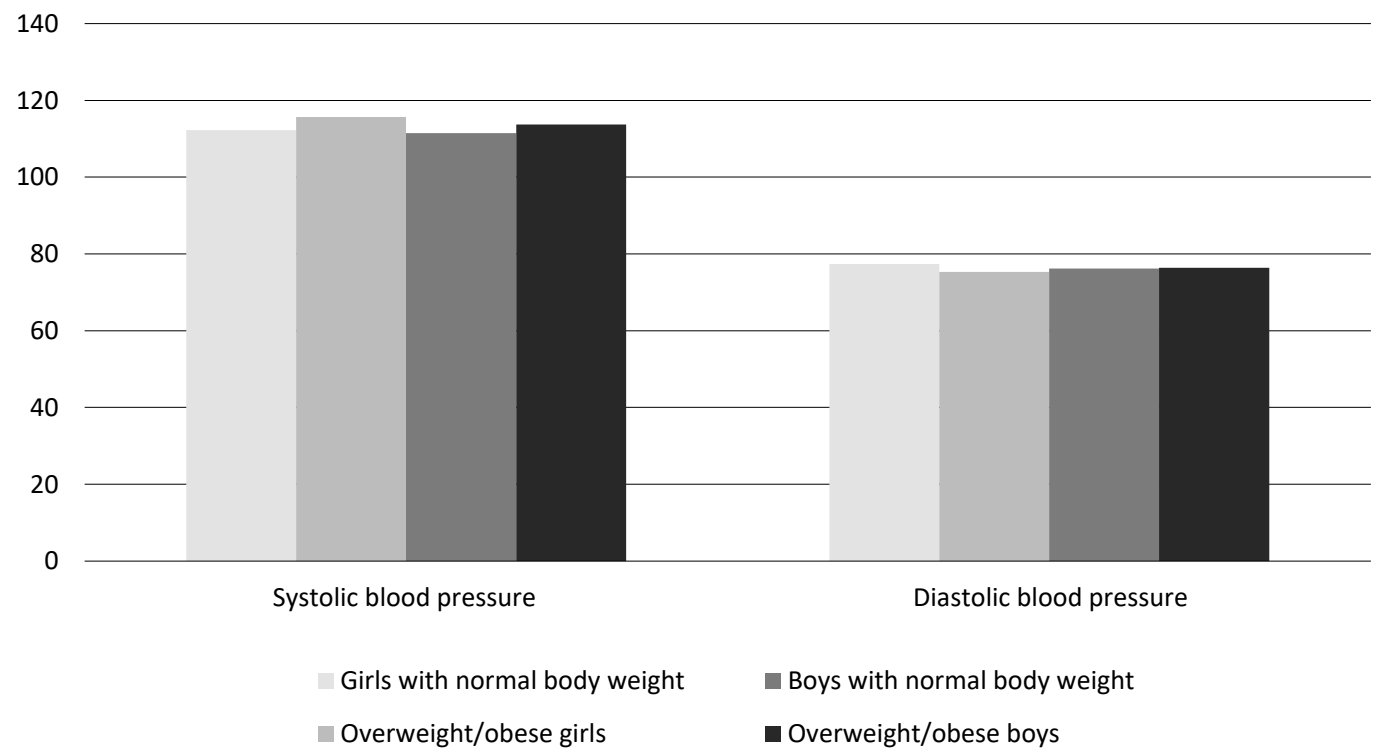

Figure 1. Systolic blood pressure and diastolic blood pressure by sex and weight

\section{Correlation between systolic and diastolic blood pressure values with salivary ghrelin and leptin concentrations}

The correlation between the salivary ghrelin and leptin concentrations and systolic and diastolic blood pressure values was analyzed. Calculations on the whole group based on Pearson's r correlation coefficient showed that systolic ( $\mathrm{p}=0.089$ for ghrelin, $\mathrm{p}=0.285$ for leptin) and diastolic ( $\mathrm{p}=0.622$ for ghrelin, $\mathrm{p}=0.284$ for leptin) blood pressure values were not correlated with the hormones' levels. Analogous analyses were performed by groups divided according to sex and weight (normal weight vs. overweight/obesity). Underweight children were excluded from the analyses. The calculated Pearson's $r$ and significance coefficients for each subgroup studied are presented in Table 9. It turned out that in the group of girls with normal body weight, diastolic pressure correlated significantly with leptin concentration (positive correlation, $\mathrm{p}=0.05$ ). In contrast, a correlation between diastolic blood pressure values and leptin levels was observed in the group of overweight/obese boys $(\mathrm{p}=0.023)$. The direction of this relationship is negative, so it appears that the higher the diastolic pressure, the lower the salivary leptin concentration. Due to the small size of the study population, these correlations should rather be treated as incipient, requiring further research and their confirmation on a larger group of children.

Table 9. Correlations between the hormones and systolic and diastolic blood pressure in the whole study group and individual subgroups

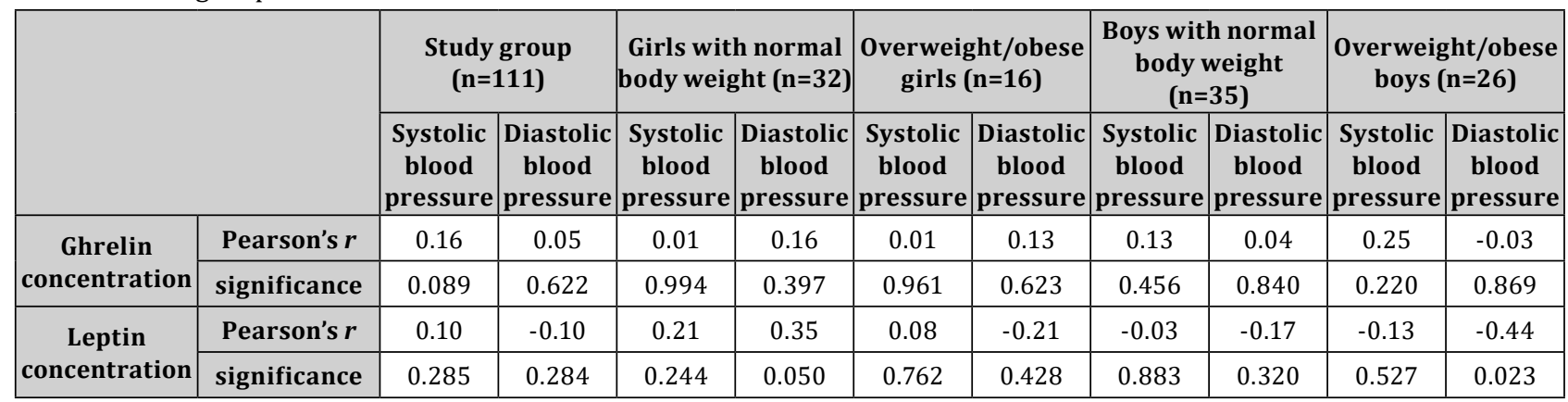

\section{Correlation between systolic and diastolic blood pressure values with weight-related variables}

Further correlation analyses were conducted to assess the association of systolic and diastolic blood pressure values with weight-related variables. Calculations, using Pearson's r correlation coefficient, were performed on the entire study group. According to the results presented in Table 10, systolic blood pressure correlates statistically significantly with weight (positive correlation, $\mathrm{p}=0.014$ ), height (positive correlation, $\mathrm{p}=0.004$ ), and waist and hip circumference (positive correlation, $\mathrm{p}<0.001$ ). Diastolic pressure, on the other hand, does not correlate with any variable related to body weight. 
Table 10. Correlations between systolic and diastolic blood pressure values and anthropometric parameters and birth weight in the whole study group $(n=111)$

\begin{tabular}{|c|c|c|c|}
\hline \multicolumn{2}{|c|}{} & Systolic blood pressure & Diastolic blood pressure \\
\hline \multirow{2}{*}{ BMI } & Pearson's $\boldsymbol{r}$ & 0.17 & 0.04 \\
\cline { 2 - 4 } & significance & 0.083 & 0.673 \\
\hline \multirow{2}{*}{ Weight } & Pearson's $\boldsymbol{r}$ & 0.23 & 0.13 \\
\cline { 2 - 4 } & significance & 0.014 & 0.174 \\
\hline \multirow{2}{*}{ Height } & Pearson's $\boldsymbol{r}$ & 0.27 & 0.14 \\
\cline { 2 - 4 } & significance & 0.004 & 0.22 \\
\hline \multirow{2}{*}{ Waist circumference } & Pearson's $\boldsymbol{r}$ & 0.32 & 0.021 \\
\cline { 2 - 4 } & significance & $<0,001$ & 0.23 \\
\hline \multirow{2}{*}{ Hip circumference } & Pearson's $\boldsymbol{r}$ & 0.36 & 0.016 \\
\cline { 2 - 4 } & significance & $<0,001$ & -0.02 \\
\hline \multirow{2}{*}{ W-H Ratio } & Pearson's $\boldsymbol{r}$ & -0.04 & 0.837 \\
\cline { 2 - 4 } & significance & 0.693 & 0.10 \\
\hline \multirow{2}{*}{ Birth weight } & Pearson's $\boldsymbol{r}$ & 0.01 & 0.300 \\
\hline
\end{tabular}

\section{Discussion}

Ghrelin and leptin are hormones whose concentrations can be determined in various biological materials (e.g., serum, plasma, or saliva) using appropriate assay methods. In the present study, salivary concentrations of the above-mentioned hormones were determined. There has been a growing interest in the use of saliva for clinical purposes in recent years.

Gröschl et al. analyzed serum and salivary ghrelin concentrations in a study involving healthy adult humans (25 subjects, 11 males and 14 females) aged 17 to 51 years with various BMI values $\left(19.5\right.$ to $\left.35 \mathrm{~kg} / \mathrm{m}^{2}\right]$. Comparison of total ghrelin values in healthy subjects (BMI between 18 and $27 \mathrm{~kg} / \mathrm{m}^{2}$ ) showed significantly lower levels of the hormone in saliva than in serum $(\mathrm{p}<0.01)$. Additionally, both saliva and serum concentrations showed a positive correlation with BMI $\left(\mathrm{r}^{2}=0.314 ; \mathrm{p}<0.01\right)$ [14].

On the other hand, Cetinkaya et al., in their study on the determination of salivary and serum ghrelin concentrations in a population of patients undergoing surgery (acute appendicitis and gallstones), also determined the concentrations of the hormone in a control group of 16 healthy subjects. It turned out that salivary ghrelin levels in healthy subjects $(87.0 \pm 8.59 \mathrm{pg} / \mathrm{ml})$ were higher than serum levels $(65.0 \pm 6.83 \mathrm{pg} / \mathrm{ml})$ in that group of patients [15].

In contrast, Aydin et al. studying a small group of young, healthy men (16 subjects) and women (14 subjects) aged 19 years with no chronic diseases, showed by analyzing the whole study group found that salivary leptin levels $(6.19 \pm 2.10 \mu \mathrm{g} / \mathrm{l})$ were lower than plasma levels $(7.39 \pm 3.23 \mu \mathrm{g} / \mathrm{l})$, while salivary ghrelin levels $(188.5 \pm 84.7$ $\mathrm{pg} / \mathrm{ml})$ were higher than plasma levels $(126.4 \pm 38.5 \mathrm{pg} / \mathrm{ml})$. There was also a weak negative correlation between plasma ghrelin concentration and BMI $(\mathrm{r}=-0.279, \mathrm{p}=0.135)$ and salivary ghrelin concentration and BMI $(\mathrm{r}=-0.186$, $\mathrm{p}=0.36$ ) in all subjects. Interestingly, a weak positive correlation was observed between plasma and salivary ghrelin levels in men $(r=0.218, p=0.416)$, while the opposite trend was shown in the female group ( $r=-0.427$, $\mathrm{p}=0.128$ ). There was also a significant negative correlation between plasma ghrelin levels and BMI in women $(\mathrm{r}=-0.509, \mathrm{p}=0.063)$. In contrast, plasma and salivary leptin concentrations were slightly lower in men compared to women [16].

Abdalla and Choo's 2020 study of young, healthy men in Malaysia showed that salivary ghrelin concentrations correlate with certain anthropometric parameters in the study population. A total of 90 adult men were included in the analysis, divided according to BMI into 4 subgroups: underweight ( $n=9)$, normal weight ( $\mathrm{n}=41)$, overweight $(n=22)$, and obese $(n=18)$. Anthropometric measurements were taken, including height, weight, waist and abdominal circumferences. Total body fat mass, visceral fat, subcutaneous fat, total and regional muscle mass were assessed by bioelectrical impedance techniques using Karad scanning. Salivary ghrelin concentrations were determined by ELISA. Abdalla and Choo's study proved that there is a positive correlation between ghrelin levels and BMI $(p=0.02)$, hip circumference $(p=0.006)$ and waist-to-hip ratio $(p=0.003)$. Moreover, the authors from Malaysia demonstrated a negative correlation of ghrelin concentration with waist circumference $(p=0.01)$ 
and waist-to-height ratio $(\mathrm{p}=0.001)$ in obese patients [17]. In another study by the same authors, salivary leptin levels were analyzed in a population of young 92 men (2 subgroups; the first ( $\mathrm{n}=51$ ) with BMI below $24.9 \mathrm{~kg} / \mathrm{m}^{2}$, the second group ( $\mathrm{n}=41)$ - overweight and obese men, BMI above $\left.25 \mathrm{~kg} / \mathrm{m}^{2}\right)$ in comparison with anthropometric measurements. They found that predictors of salivary leptin levels in adult healthy men are different in normal weight and obese subjects. The most important predictor of salivary leptin concentration is hip circumference in normal-weight and underweight individuals, whereas height is the most important in healthy overweight and obese adult men [18].

The studies conducted to date on ghrelin and leptin concentrations, both in saliva and serum, are primarily on adults. Scientific reports on this topic involving early childhood and adolescent populations are scarce and usually involve studies conducted in small groups and in populations of children in different age categories. Hence, it is extremely difficult to compare results obtained by researchers around the world, in populations of children of different ages, foreign cultures, and with different dietary norms and habits. Nevertheless, in this study, an effort was made to cite what the authors believe to be the most important findings regarding salivary ghrelin and leptin determinations among children.

In 2010, Li and colleagues showed a positive correlation between ghrelin concentration in blood and saliva with BMI. The study involved 194 children between the ages of 7 and 18 living in China (average age 12.98 years) who had saliva and blood samples taken for testing. Patients were neither taking any permanent medications nor were burdened with any diseases affecting body metabolism. Anthropometric measurements were taken, and BMI values were determined from these measurements. Four groups of subjects were formed including lean, underweight $(\mathrm{n}=79)$, normotensive $(\mathrm{n}=33)$, overweight $(\mathrm{n}=37)$, and obese $(\mathrm{n}=45)$. Saliva and blood samples were collected simultaneously between 8:30 and 10:00 am. Before the study, patients were properly prepared, fasted, and were not allowed to smoke. The study determined that children's serum ghrelin levels ranged from 0.87 to $434.28 \mathrm{pg} / \mathrm{ml}$, and saliva levels ranged from 0.06 to $162.97 \mathrm{pg} / \mathrm{ml}$. It was further demonstrated that ghrelin levels in lean subjects were significantly lower than in other groups, both in serum and saliva. There was a positive correlation between salivary ghrelin and serum concentrations of the hormone $(p<0.01)$. Serum and saliva ghrelin levels were significantly correlated with BMI ( $r=0.523, r=0.374, p<0.01$, respectively), but not with plasma lipid (total cholesterol, LDL cholesterol, HDL cholesterol, and triglyceride) levels [19].

A study by Pirsean et al. conducted in Romania in 2019 in a group of 17 urban-dwelling children diagnosed as overweight or obese and 5 normal-weight children who reported to the center of the study in question for annual standard analysis and health assessment showed that salivary concentrations of proinflammatory cytokines in overweight/obese children: IL-6 $(41 \mathrm{ng} / \mathrm{ml} \pm 21)$ and leptin $(40.4 \mathrm{ng} / \mathrm{ml} \pm 28.8)$ are significantly increased compared to normal weight children (IL-6 $8.1 \pm 4.6$, leptin 9.58 \pm 3.1 ). Salivary leptin concentrations were 3 -fold higher in the group of children struggling with obesity or overweight compared to the control group of normalweight children $(\mathrm{p}<0.01)$. Interestingly, salivary leptin levels were not correlated with either BMI $(\mathrm{r}=0.1, \mathrm{p}=0.68)$ or age $(r=0.03, p=0.07)$. The highest leptin levels were found in an obese child ( $>99$ th percentile) who was also diagnosed with bronchial asthma $(97.5 \mathrm{ng} / \mathrm{ml})$ associated with increased IL-6 levels $(58.6 \mathrm{ng} / \mathrm{ml})$ [20].

Rodrigues et al. in 2017 in Portugal in an interesting study examined whether salivary leptin levels are associated with taste perception in children and whether children's BMI affects this relationship. Sweet and bitter taste sensitivity was assessed in a population of 121 children aged 9-10 years ( 60 boys and 61 girls) using pre-prepared samples with increasing concentrations of glucose and caffeine solutions. Saliva was also collected for quantification of leptin using ELISA. There were no statistically significant differences in salivary leptin levels between genders (boys and girls, $10.41 \pm 0.76 \mathrm{pg} / \mathrm{mL}$ and $9.28 \pm 0.63 \mathrm{pg} / \mathrm{mL}$, respectively ( $\mathrm{p}=0.255$ )). There were also no differences in leptin concentrations in comparison with BMI. In normal weight, overweight and obese children, the concentrations of this compound were comparable. There was also a positive correlation between sensitivity to sweet taste and salivary leptin concentration in girls $(r=0.263 ; p=0.046 ; n=58)$, while no such correlation was found in boys $(r=0.058 ; p=0.659 ; n=60)$. In contrast, higher salivary leptin concentrations were observed in children with lower sensitivity to bitter taste (this association was shown only in overweight boys). No differences were found in girls [21].

Jang et al. studied the phenomenon of hyperleptinemia in a population of children with precocious puberty in 2014-2015. The study group consisted of 325 children (273 girls and 52 boys) with early or precocious puberty exhibiting abnormally high blood leptin levels $(>7.8 \mathrm{ng} / \mathrm{ml})$ who presented to the research center for gonadotropin-releasing hormone ( $\mathrm{GnRH})$ stimulation testing. The mean age of the children was $9.2 \pm 1.7$ years. Of them, 254 (78\%) did not have weight disorders, while 71 children $(22 \%)$ were obese. It turned out that blood leptin levels were significantly higher in the group of obese children compared to the healthy group, $17.0 \pm 7.8 \mathrm{ng} /$ $\mathrm{ml}$ vs $12.6 \pm 4.9 \mathrm{ng} / \mathrm{ml}$, respectively $(\mathrm{p}<0.001)$. In a population of obese children, blood leptin levels in boys were significantly higher than in girls, $23.2 \pm 11.2 \mathrm{ng} / \mathrm{ml}$ vs $16.1 \pm 6.8 \mathrm{ng} / \mathrm{ml}$, respectively $(\mathrm{p}<0.05)$ [22]. 
In a large study conducted in 2012 in Kuwait, Goodson et al. sought to determine the concentrations of various compounds as potential markers for assessing the metabolic status of children in collected saliva samples. The study included 8319 children, but only 744 children aged 10-12 years were selected for the assessment of nutritional disorders, anthropometric evaluation, and calculation of BMI. Nutritional status was assessed by comparison to growth charts. Concentrations of C-reactive protein (CRP), insulin, leptin, and adiponectin were determined in collected saliva samples. It was found that CRP content was 6 -fold higher, salivary insulin and leptin levels were 3 -fold higher, and adiponectin levels were 30\% lower in obese children compared to healthy normal weight children $(\mathrm{p}<0.0001)$. CRP and insulin concentrations were significantly elevated in obese children compared with normal weight children. Salivary insulin levels in obese subjects (mean concentration $=127 \mathrm{pg}$ / $\mathrm{ml}$ ) were almost 3 times higher than in normal weight subjects (mean concentration $=44 \mathrm{pg} / \mathrm{ml}$ ), and salivary CRP levels in obese subjects (mean concentration $=435 \mathrm{pg} / \mathrm{ml}$ ) were almost 6 times higher compared to normal weight children (mean concentration $=76 \mathrm{pg} / \mathrm{ml}$ ). In contrast, specific salivary leptin levels in obese children (mean concentration $=3.3 \mathrm{pg} / \mathrm{ml}$ ) were found to be 3 times higher than in the population of normal weight children $(1 \mathrm{pg} / \mathrm{ml})$. Moreover, no significant differences were found between the concentrations of selected compounds among underweight and normal weight children [23].

Idris et al. determined salivary leptin concentrations in a group of children living in Brunei. The study design involved 374 children, but only 169 high school students between the ages of 11 and 18 agreed to participate in the experiment (response rate 45\%). Subjects were asked to complete questionnaires, anthropometric measurements (height and weight) were taken, and saliva samples were collected. No physical examinations were performed during data collection, which may be seen as a limitation of this study. Of the 169 saliva samples obtained, 40 were excluded from analysis due to the low percent coefficient of variation ( $>10 \%)$. Another 34 samples were excluded because the measured salivary leptin concentration was below the detection threshold $(2 \mathrm{pg} / \mathrm{ml})$. Therefore, 95 saliva samples were finally qualified for analysis, of which 37 were collected from boys and 58 from girls. In the boy population, $54 \%(n=20)$ had a BMI $\geq 22 \mathrm{~kg} / \mathrm{m}^{2}$ (which was defined as overweight), whereas, in the girl population, overweight was found among $31 \%$ of them $(n=18)$. The mean salivary leptin levels in boys were $24.79 \pm 18.80 \mathrm{pg} / \mathrm{ml}$, while in the girl population, they were within $32.74 \pm 22.08 \mathrm{pg} / \mathrm{ml}$. There was no significant correlation between salivary leptin levels in normal weight children and salivary leptin levels in overweight children, regardless of gender, taking into account the age. It was shown that salivary leptin concentrations were similar in boys and girls [24].

Martinez et al. in their study determined the correlation between glucose, insulin and selected adipocy tokines levels and the Homeostasis Model Assessment of Insulin Resistance (HOMA-IR) index in relation to the presence or absence of the FTO rs9939609 (fat mass and obesity-associated gene) gene polymorphism, rs1801282 gene polymorphism for peroxisome proliferator-activated receptor (PPAR $\gamma$ ), and single nucleotide polymorphism (SNP) as indicators of variation in body weight and BMI in adolescents. The study was conducted in Mexico in 2016 and included 71 students ages 14-18. The children underwent various anthropometric and blood laboratory measurements, including a lipid profile, glucose, insulin and adipocy tokine levels, and HOMA index. The degree of association between variables was assessed with respect to the presence or absence of SNPs. It turned out that serum leptin levels were significantly higher among girls $(p=0.001)$, although adiponectin levels were not significantly different $(\mathrm{p}=0.060)$. Positive correlations were also found between insulin levels and HOMA index and obesity susceptibility gene (FTO) $(r=0.391, p=0.007 ; \mathrm{r}=0.413, \mathrm{p}=0.005$, respectively) and PPAR $\gamma$ and SNP $(r=0.529, p=0.007 ; r=0.537, p=0.007$, respectively). Leptin concentrations showed a positive correlation in the context of the presence of PPAR $\gamma$ polymorphism ( $r=0.483 ; p=0.007)$ regardless of the presence or absence of SNP $(\mathrm{r}=0.627 ; \mathrm{p}=0.039)$. Therefore, it seems that the presence of the studied gene polymorphisms may be associated with a genetic predisposition to metabolic syndrome in adolescents [25].

\section{Conclusions}

Based on the results of this study, it can be concluded that the concentrations of ghrelin and leptin in saliva in the selected population of overweight or obese children were significantly higher compared to children with normal body weight. However, no gender differences were observed. Thus, it can be concluded that the differentiating factor between salivary ghrelin and leptin concentrations is body weight (normal weight vs. overweight/ obesity), while gender has no effect on the concentrations of the hormones in question. The concentrations of ghrelin and leptin are interdependent. The results also showed that weight-related variables including BMI, body mass, height, waist circumference, hip circumference and waist/hip ratio correlate significantly with salivary ghrelin and leptin concentrations. The baby's birth weight has no effect on the concentrations of the studied hormones. From the results obtained it can be concluded that systolic and diastolic blood pressure values are 
not correlated with the discussed compounds levels. As expected, it was also possible to prove that systolic blood pressure values correlate statistically significantly with children's body weight, height and waist and hip circumference. Due to the small size of the study population, it seems necessary to deepen the discussed topic and further scientific work. According to the authors, it would be valuable to extend the study in subsequent steps by analyzing the concentrations of other compounds affecting body metabolism in children's saliva, such as adiponectin, visfatin, resistin, interleukins, and to correlate the obtained data with the concentrations of basic biochemical laboratory parameters of children's serum (including glucose, glycated hemoglobin, CRP, lipidogram, or TSH). Nevertheless, non-invasive examination of compounds found in saliva may be a valuable diagnostic tool for various diseases, including metabolic disorders, in the future.

\section{Disclosures and acknowledgements}

The study was conducted within the scope of financing of the scientific-research work under the contract no. KNW-2-029/D/9/N for the realization of scientific-research work by a PhD student of the Medical University of Silesia in Katowice, Poland.

\section{References:}

1. Jonczyk P, Potempa M, Janerka M, Kucharzewski M. [Ghrelin - hormone which regulates the energy metabolism of the body. Part 1 . Synthesis, secretion, mechanism of action, clinical significance]. Medycyna Metaboliczna. 2014; 18(3): 66-73 (in Polish).

2. Polińska B, Matowicka-Karna J, Kemona H. [The role of ghrelin in the organism]. Postepy Hig Med Dosw (online). 2011; 65: 1-7 (in Polish). https://doi.org/10.5604/17322693.931085

3. Jonczyk P, Potempa M, Janerka M, Kucharzewski M. [Ghrelin - a small peptide, high capabilities]. Edukacja Biologiczna i Środkowiskowa. 2015; 2: 38-50 (in Polish).

4. Skowrońska B, Fichna M, Fichna P. [The role of adipose tissue in the endocrine system]. Endocrinol Obes Metab Disord. 2005; 1(3): 21-29 (in Polish).

5. Gogga P, Karbowska J, Meissner W, Kochan Z. [Role of leptin in the regulation of lipid and carbohydrate metabolism]. Postepy Hig Med Dosw (online). 2011; 65: 255-262 (in Polish). https://doi.org/10.5604/17322693.940259

6. Niemczyk S, Romejko-Ciepielewska K, Niemczyk L. Adipocytokines and sex hormones disorders in patients with chronic renal failure. Polish Journal of Endocrinology. 2012; 63 (2): 148-155.

7. Stachowicz M, Janas-Kozik M, Olszanecka-Glinianowicz M, Chudek J. [Role of leptin in eating disorders current concept]. Psychiatr. Pol. 2013; 47(5): 897-907 (in Polish).

8. Śledzińska M, Liberek A, Kamińska B. [Fat hormones and obesity in children and adolescents]. Medycyna Wieku Rozwojowego. 2009; 13(4): 244-251 (in Polish).

9. Otto-Buczkowska E, Chobot A. Role of ghrelin and leptin in the regulation of carbohydrate metabolism. Part I. Ghrelin. Postepy Hig Med Dosw (online). 2012; 66: 795-798. https://doi.org/10.5604/17322693.1015532

10. Jonczyk P, Potempa M, Janerka M, Kucharzewski M. [Ghrelin - hormone which regulates the energy metabolism of the body, clinical significance. Part 2. Influence on carbohydrate and lipid metabolism]. Medycyna Metaboliczna. 2014; 18(3): 74-82 (in Polish).

11. Cummings DE, Foster KE. Ghrelin-leptin tango in body-weight regulation. Gastroenterology. 2003; 124: 1532-5. https://doi.org/10.1016/S0016-5085(03)00350-0

12. Çalışır H, Güneş Z, Özvurmaz S. Perception of health, obesity risk and dietary habits in youth. Health Prob Civil. 2019; 13(1): 60-66. https://doi.org/10.5114/hpc.2018.78784

13. Jonczyk P, Potempa M, Kajdaniuk D. Level of nutrition and nutrition disorders as well as characteristics of dietary habits and physical activity among 6-13-year-old children attending selected primary schools in Opole and Silesia Provinces in Poland. Pediatr Med Rodz. 2016; 12 (2): 177-193. https://doi.org/10.15557/PiMR.2016.0018

14. Gröschl M, Topf HG, Bohlender J, Zenk J, Klussmann S, Dötsch J, et al. Identification of ghrelin in human saliva: production by the salivary glands and potential role in proliferation of oral keratinocytes. Clin Chem. 2005; 51(6): 997-1006. https://doi.org/10.1373/clinchem.2004.040667

15. Cetinkaya Z, Aydin S, Cerrahoglu YZ, Ayten R, Erman F, Aygen E. Changes in appetite hormone (ghrelin) levels of saliva and serum in acute appendicitis cases before and after operation. Appetite. 2009; 52(1): 104107. https://doi.org/10.1016/j.appet.2008.09.001 
16. Aydin S, Halifeoglu I, Ozercan IH, Erman F, Kilic N, Aydin S, et al. A comparison of leptin and ghrelin levels in plasma and saliva of young healthy subjects. Peptides. 2005; 26(4): 647-652. https://doi.org/10.1016/j. peptides.2004.11.008

17. Abdalla MMI, Choo SS. The association between salivary ghrelin levels with anthropometric measures in underweight, normal, overweight and obese healthy adult males. Eur Endocrinol. 2020; 16(1): 49-53. https://doi.org/10.17925/EE.2020.16.1.49

18. Abdalla MMI, Choo SS. Salivary leptin level in young adult males and its association with anthropometric measurements, fat distribution and muscle mass. Eur Endocrinol. 2018; 14(2): 94-98. https://doi.org/10.17925/EE.2018.14.2.94

19. Li BB, Chen ZB, Li BC, Lin Q, Li XX, Li SL, et al. Expression of ghrelin in human salivary glands and its levels in saliva and serum in Chinese obese children and adolescents. Arch Oral Biol. 2011; 56(4): 389-394. https://doi.org/10.1016/j.archoralbio.2010.10.014

20. Pîrsean C, Neguț C, Stefan-van Staden RI, Dinu-Pirvu CE, Armean P, Udeanu DI. The salivary levels of leptin and interleukin-6 as potential inflammatory markers in children obesity. PLoS One. 2019; 14(1): e0210288. https://doi.org/10.1371/journal.pone.0210288

21. Rodrigues L, Espanca R, Costa AR, Antunes CM, Pomar C, Capela-Silva F, et al. Association between salivary leptin levels and taste perception in children. J Nutr Metab. 2017; 2017: 7260169. https://doi.org/10.1155/2017/7260169

22. Jang KM, Moon JE, Cho EM, Choi BH, Ko CW. Hyperleptinemia in obese and non-obese children with early puberty. Abstracts from the 9th Biennial Scientific Meeting of the Asia Pacific Paediatric Endocrine Society (APPES) and the 50th Annual Meeting of the Japanese Society for Pediatric Endocrinology (JSPE). International Journal of Pediatric Endocrinology. 2017; Suppl 1: 15. https://doi.org/10.1186/s13633-0170054-x

23. Goodson JM, Kantarci A, Hartman ML, Denis GV, Stephens D, Hasturk H, et al. Metabolic disease risk in children by salivary biomarker analysis. PLoS One. 2014; 9(6): e98799. https://doi.org/10.1371/journal. pone.0098799

24. Idris A, Khamis AG, Ghazali NB, Steele M, Koh D, Tuah NA. Salivary leptin concentrations in Bruneian secondary school children. Asian Pacific Journal of Tropical Biomedicine. 2016; 6(4): 335-337. https://doi.org/10.1016/j.apjtb.2016.01.003

25. Martínez-Martínez MD, Mendieta-Zerón H, Celis L, Layton-Tovar CF, Torres-García R, Gutiérrez-Pliego LE, et al. Correlation of the homeostasis model assessment index and adiponectin, leptin and insulin levels to body mass index-associated gene polymorphisms in adolescents. Sultan Qaboos Univ Med J. 2018; 18(3): e291-e298. https://doi.org/10.18295/squmj.2018.18.03.005 